\title{
Effect of Fertilizer Management on NPKS Leaching Loss from Sandy Loam Soil under Alternate Wetting and Drying Condition
}

\author{
M N Islam¹*, M M Rahman², M J A Mian³ and M H Ali
}

\begin{abstract}
Leaching loss of nutrients hampers plant growth and contributes to environmental pollution. An experiment was conducted at the net house of Soil Science Department, Bangladesh Agricultural University, Mymensingh during January to May 2009 to find out the leaching loss of N, P, K and S from sandy loam soil. Each pot received $6.67 \mathrm{~kg}$ dry soil with an opening at the bottom for collecting leachates. Six treatments were used: $T_{0}=$ control, $T_{1}=$ NPKS $\left(120,25,60\right.$ and $\left.20 \mathrm{~kg} \mathrm{ha}^{-1}\right), \mathrm{T}_{2}=\mathrm{NPKS}$ $\left(180,37,90\right.$ and $\left.30 \mathrm{~kg} \mathrm{ha}^{-1}\right), \mathrm{T}_{3}=\mathrm{NPKS}\left(90,5,28\right.$ and $\left.17 \mathrm{~kg} \mathrm{ha}^{-1}\right)+\operatorname{cowdung}\left(2.5 \mathrm{t} \mathrm{ha}^{-1}\right), \mathrm{T}_{4}=\mathrm{NPKS}$ $\left(109,25,60\right.$ and $20 \mathrm{~kg} \mathrm{ha}^{-1}, \mathrm{~N}$ as USG) and $\mathrm{T}_{5}=$ as $\mathrm{T}_{1}$ but $\mathrm{N}$ applied as foliar spray. Treatments were arranged in a completely randomized design with three replications. Leachates were collected at 15 days interval for determination of NPKS. The total leaching loss of N, P, K and S due to different treatments ranged from 16.00 to $90.21,0.07$ to $0.29,9.60$ to 11.20 and 3.75 to $17.81 \mathrm{~kg} \mathrm{ha}^{-1}$, respectively. Application of chemical fertilizer at higher rates resulted in greater loss of nutrients. Integrated fertilizer management with cowdung $\left(\mathrm{T}_{3}\right)$ minimized such losses. Use of USG also reduced leaching loss of N, P, K and S. The application of cowdung and USG with recommended balanced fertilizer might be useful for minimizing N, P, K and $\mathrm{S}$ loss from wetland rice field.
\end{abstract}

Key words: Leaching loss, Sandy loam soil, AWD, Boro rice

\section{INTRODUCTION}

Fertilizers are indispensable in modern agriculture and their uses are increasing over time. Chemical fertilizers are the key of successful crop production in Bangladesh (BARC, 1997). When we apply fertilizer for obtaining maximum crop production, a significant amount of nutrients are lost by leaching with water. This leaching loss depends on soil properties and rates of nutrients used. Nearly all nitrogen $(\mathrm{N})$ fertilizers are completely water soluble and a significant portion is lost through leaching. Nitrate leaching occurs when soil $\mathrm{NO}_{3}-\mathrm{N}$ concentrations are high and water moves beyond the root zone. In well-drained sandy soils, much of the $\mathrm{NO}_{3}$ can be lost by leaching (Camberato et al., 2008). Standing water for a long time favours more leaching loss than saturation or alternate wetting and drying (AWD). Surface application of $\mathrm{N}$-fertilizers in light textured soil causes more $\mathrm{NO}_{3}$ loss. Application of $\mathrm{N}$-fertilizers at higher doses cause higher leaching loss (Sahu and Samant, 2006). Sahu and Samant (2006) reported that soils having low organic matter status cause more $\mathrm{N}$ leaching loss than organic matter rich soil. It is estimated that upland lateritic sandy loam soils at Bhubaneswar caused 23-24\% loss of applied N. Leaching losses in rice field studied in sandy loam mixed red and black soils of Hirakud command area were $45-46 \%$ under saturated condition and $80-84 \%$ under submerged condition. de Oliveira et al., (2002) found the largest $\mathrm{N}$ losses in the first three weeks. Phosphorus (P) is less mobile in soil and leaching loss is lower as compared to

${ }^{1}$ Scientific Officer, Soil Science Division, BRRI, Gazipur; 2 \& 3Professor, Department of Soil Science, BAU; ${ }^{4}$ Scientific Officer, Irrigation and Water Management Division, BRRI, Gazipur, Bangladesh. *Corresponding author's E-mail: nazrulag@gmail.com 
other nutrients. Besides, phosphate binds strongly with aluminum, iron, manganese, calcium and other elements present in the soils at relatively higher levels (Hodges, 2010). A major portion of $\mathrm{P}$ fertilizer is fixed quickly when added to soil. Phosphorus losses vary depending upon amount, intensity, and duration of rainfall (Sharpley, 1997). The risk of $\mathrm{K}$ leaching loss is very high, especially when generous rates of $\mathrm{K}$ fertilizers are applied (Pieri et al., 1986). The average leached $\mathrm{N}$ during the experimental period of 11 months was of $4.5 \mathrm{~kg} \mathrm{ha}^{-1}$. The mean losses of $\mathrm{K}^{+}, \mathrm{Ca}^{2+}$ and $\mathrm{Mg}^{2+}$ were of 13,320 and $80 \mathrm{~kg}$ $\mathrm{ha}^{-1}$, respectively. The amount of sulphate lost by leaching tended to increase with the amount of drainage. However, such leaching studies are very little under different soil, water and agro-climatic conditions of Bangladesh. The present study was undertaken with the objectives of determining the leaching loss of N, P, K and $S$ in sandy loam soil under AWD condition.

\section{MATERIALS AND METHODS}

An experiment was conducted at the net house of Soil Science Department, Bangladesh Agricultural University, Mymensingh from January to May, 2009 to study the leaching loss of NPKS under AWD condition. Soil was sandy loam (Old Brahmaputra Floodplain Soil, AEZ-9) in texture $(46.8 \%$ sand, $48 \%$ silt and $5.2 \%$ clay) having $\mathrm{pH}, 6.6$; total $\mathrm{N}, 0.08 \%$; available $\mathrm{P}, 7.00 \mu \mathrm{g} \mathrm{g}^{-1}$; exchangeable $\mathrm{K}, 0.07$ cmol $\mathrm{kg}^{-1}$ and available $\mathrm{S}, 7.5 \mu \mathrm{g} \mathrm{g}^{-1}$, respectively. Each pot received $6.67 \mathrm{~kg}$ soil (dry basis) with an opening at the bottom for collecting leachates. The upper surface area of the pot was $380 \mathrm{~cm}^{2}$. BRRI dhan29 was used as the test variety. The treatments imposed were: $T_{0}=$ control, $T_{1}=\operatorname{NPKS}(120,25,60$ and $20 \mathrm{~kg} \mathrm{ha}-1), \mathrm{T}_{2}=\operatorname{NPKS}(180,37,90$ and $30 \mathrm{~kg}$ ha-1), $\mathrm{T}_{3}=\operatorname{NPKS}\left(90,5,28\right.$ and $\left.17 \mathrm{~kg} \mathrm{ha}^{-1}\right)+$ cowdung (2.5 $\left.\mathrm{t} \mathrm{ha}^{-1}\right), \mathrm{T}_{4}=\mathrm{NPKS}(109,25,60$ and $20 \mathrm{~kg} \mathrm{ha}^{-1}, \mathrm{~N}$ as USG) and $\mathrm{T}_{5}=$ as $\mathrm{T}_{1}$ but $\mathrm{N}$ applied as foliar spray. Treatments were arranged in a completely randomized design with three replications. Nitrogen, $\mathrm{P}, \mathrm{K}$ and S content in cow dung was 1.2, 0.8, 1.3 and $0.13 \%$, respectively. All the fertilizers except urea were applied as basal. Urea was applied in three equal splits at 10, 35 and 58 days after transplanting (DAT). In $\mathrm{T}_{4}$, one piece of USG $(0.90 \mathrm{~g})$ was placed in each pot at 10 DAT. In $\mathrm{T}_{5}$, one-third urea was applied at $10 \mathrm{DAT}$ and the rest was sprayed as 3\% urea solution in 6 equal splits at 10 days interval after first application.

Leachates from individual pots were collected at 15 days interval and analyzed for $\mathrm{N}$ content by rapid test method using soil testing kit, P by Olsen method (Olsen et al., 1954), K by flame photometer (Black, 1965) and $S$ by turbidimetric method (Page et al., 1989). In case of initial soil analysis total $\mathrm{N}$ content was determined by micro-Kjeldhal method (Page et al., 1989), texture by hydrometer method (Black, 1965) and $\mathrm{pH}$ by glass electrode $\mathrm{pH}$ meter (Black, 1965).

Analysis of variance, variation in means and standard error for the treatment effect were analyzed using IRRISTAT software version 4.1 .

\section{RESULTS AND DISCUSSION}

Figures 1, 2, 3, 4 and 5 present the patterns of leaching loss $\left(\mathrm{mg} \mathrm{kg}^{-1}\right)$ of $\mathrm{NH}_{4}{ }^{+}-\mathrm{N}, \mathrm{NO}_{3}-\mathrm{N}, \mathrm{P}, \mathrm{K}$ and $\mathrm{S}$ under different treatments. All the treatments resulted in more leaching loss compared to control. The maximum leaching loss of nutrients was recorded due to application of fertilizers at higher rates $\left(\mathrm{T}_{2}\right)$. The loss of $\mathrm{N}$ was the highest when urea was applied at higher rates, which were followed by urea application at recommended dose either as splits or foliar sprays (Fig. 1 and 2). The loss of $\mathrm{NH}_{4}{ }^{+}-\mathrm{N}$ in $\mathrm{T}_{1}$ was $30 \mathrm{mg} \mathrm{kg}^{-1}$ at $15 \mathrm{DAT}$, which was reduced by $10 \%$ at 30 DAT. 


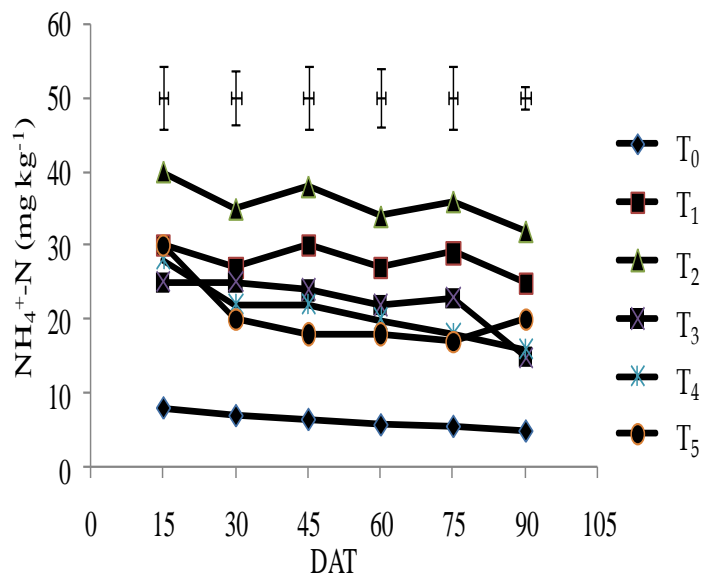

Fig. 1. Leaching loss of $\mathrm{NH}_{4}{ }^{+}-\mathrm{N}$.

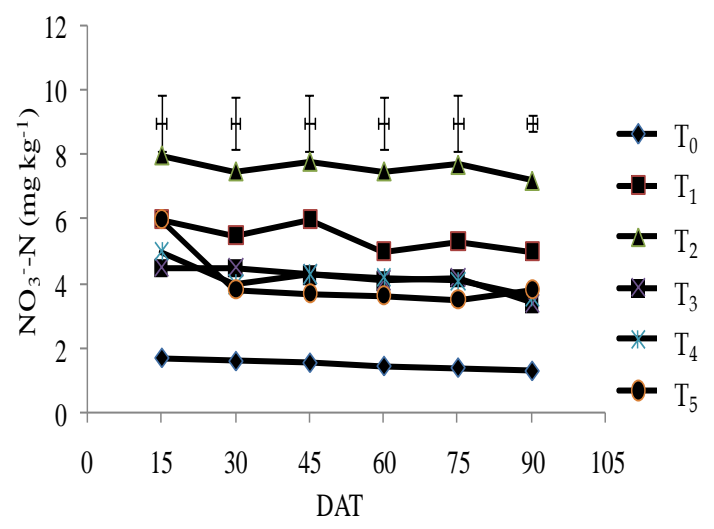

Fig. 2. Leaching loss of $\mathrm{NO}_{3}^{-}-\mathrm{N}$.

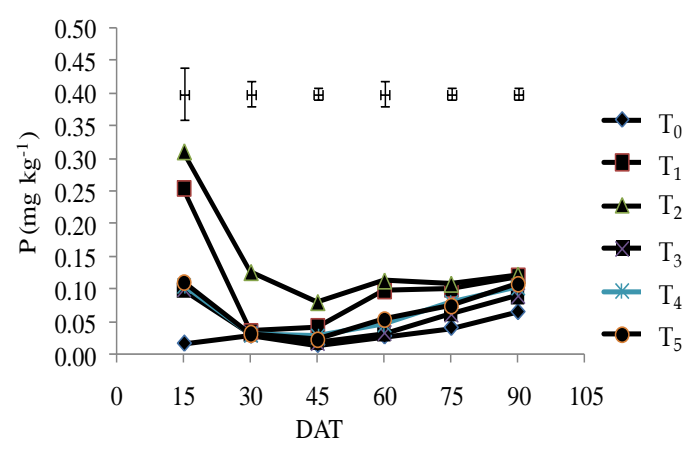

Fig. 3. Leaching loss of available P.

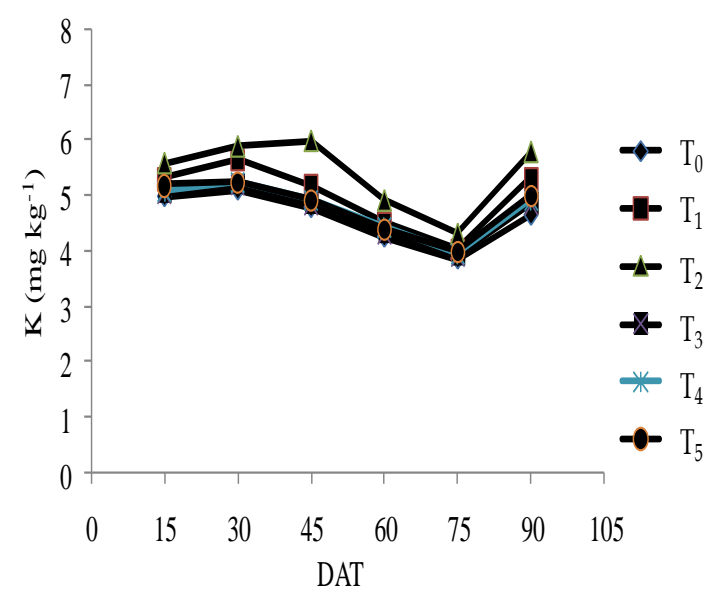

Fig. 4. Leaching loss of available K.

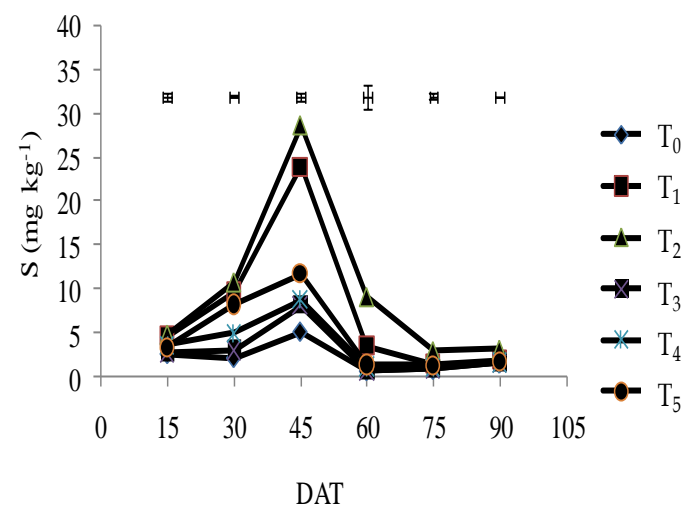

Fig. 5. Leaching loss of available S.

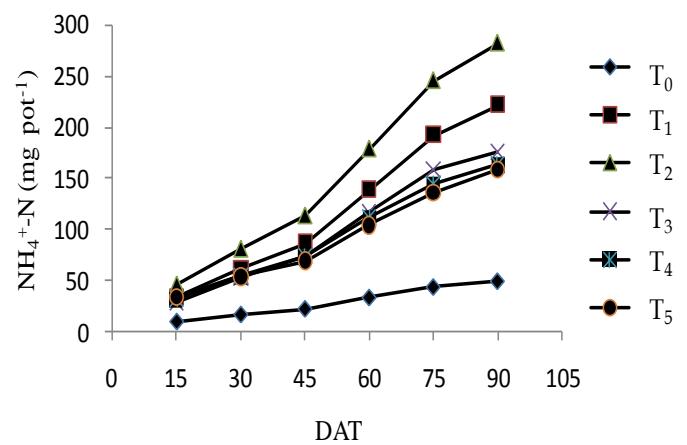

Fig. 6. Cumulative leaching loss of $\mathrm{NH}_{4}{ }^{+}-\mathrm{N}$.

Vertical bars at the top of figure indicate standard error.

$\mathrm{T}_{0}=$ control, $\mathrm{T}_{1}=\operatorname{NPKS}\left(120,25,60\right.$ and $\left.20 \mathrm{~kg} \mathrm{ha}^{-1}\right), \mathrm{T}_{2}=\operatorname{NPKS}\left(180,37,90\right.$ and $\left.30 \mathrm{~kg} \mathrm{ha}^{-1}\right), \mathrm{T}_{3}=\mathrm{NPKS}(90,5$, 28 and $\left.17 \mathrm{~kg} \mathrm{ha}^{-1}\right)+$ cowdung $\left(2.5 \mathrm{tha}^{-1}\right), \mathrm{T}_{4}=\operatorname{NPKS}\left(109,25,60\right.$ and $20 \mathrm{~kg} \mathrm{ha}^{-1}, \mathrm{~N}$ as USG $)$ and $\mathrm{T}_{5}=$ as $\mathrm{T}_{1}$ but $\mathrm{N}$ applied as foliar spray. 


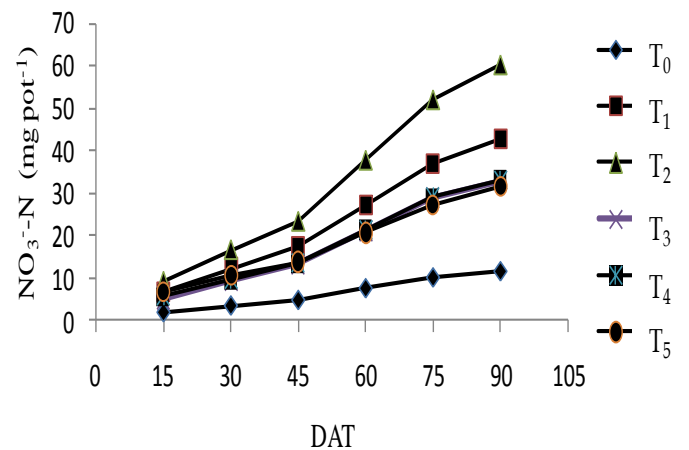

Fig. 7. Cumulative leaching loss of $\mathrm{NO}_{3}-\mathrm{N}$.

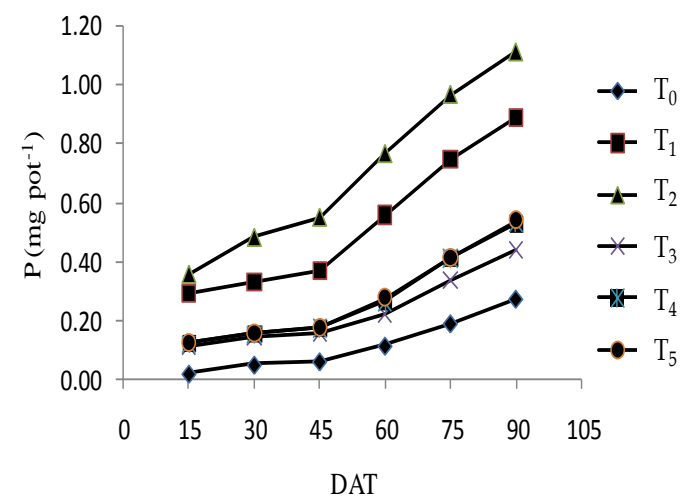

Fig. 8. Cumulative leaching loss of available P.

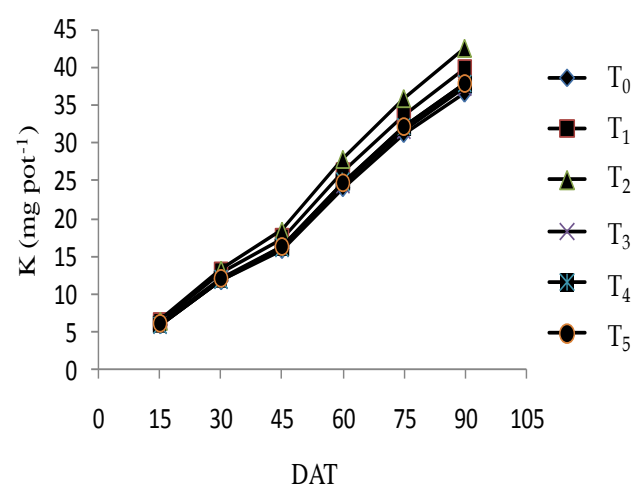

Fig. 9. Cumulative leaching loss of available K.

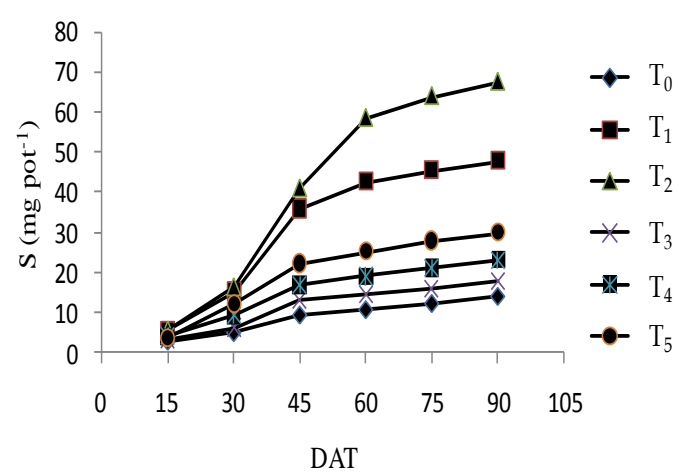

Fig. 10. Cumulative leaching loss of available S.

$\mathrm{T}_{0}=$ control, $\mathrm{T}_{1}=\operatorname{NPKS}\left(120,25,60\right.$ and $\left.20 \mathrm{~kg} \mathrm{ha}^{-1}\right), \mathrm{T}_{2}=\mathrm{NPKS}\left(180,37,90\right.$ and $\left.30 \mathrm{~kg} \mathrm{ha}^{-1}\right), \mathrm{T}_{3}=\mathrm{NPKS}(90,5$, 28 and $\left.17 \mathrm{~kg} \mathrm{ha}^{-1}\right)+$ cowdung $\left(2.5 \mathrm{t} \mathrm{ha}^{-1}\right), \mathrm{T}_{4}=\operatorname{NPKS}\left(109,25,60\right.$ and $20 \mathrm{~kg} \mathrm{ha}^{-1}, \mathrm{~N}$ as USG) and $\mathrm{T}_{5}=$ as $\mathrm{T}_{1}$ but $\mathrm{N}$ applied as foliar spray.

At 45 DAT, the amount of $\mathrm{NH}_{4}{ }^{+}-\mathrm{N}$ loss increased again and then almost static up to 75 DAT but sharply reduced by $16.67 \%$ at 90 DAT, a loss of $25 \mathrm{mg} \mathrm{kg}^{-1}$. Similarly, loss of $\mathrm{NO}_{3}-\mathrm{N}$ at 15 DAT was $6 \mathrm{mg} \mathrm{kg}^{-1}$, which reduced by $8.33 \%$ at $30 \mathrm{DAT}$. But amount of loss, increased at 45 DAT. Intensity of $\mathrm{N}$ losses increased after urea top dressing. Almost similar trend was found with other treatments except USG application. With USG, loss was very high at 15 DAT. Phosphorous loss was the highest at 15 DAT in comparison to 45, 60, 75 and 90 DAT (Fig.
3). The loss of $P$ in $T_{1}$ was $0.254 \mathrm{mg} \mathrm{kg}^{-1}$ at 15 DAT, which reduced by $85.83 \%$ at 30 DAT (a loss of $0.036 \mathrm{mg} \mathrm{kg}^{-1}$ ) and then almost static up to 90 DAT. It might be due to the decrease of $\mathrm{P}$ release or availability over time. Potassium loss was more up to 45 DAT and this loss was reduced at 60 and 75 DAT (Fig. 4). Less $\mathrm{K}$ loss at 60 and 75 DAT might be due to more requirement and $\mathrm{K}$ uptake for grain formation. Sulfur loss increased up to 45 DAT and then gradually decreased (Fig. 5). Above results supported the findings of Islam et al., (2013b) and Islam et al., (2014). 
Figures 6, 7, 8, 9 and 10 present the cumulative leaching loss patterns $\left(\mathrm{mg}\right.$ pot $\left.^{-1}\right)$ of $\mathrm{NH}_{4}{ }^{+}-\mathrm{N}, \mathrm{NO}_{3}-\mathrm{N}, \mathrm{P}, \mathrm{K}$ and $\mathrm{S}$. The highest cumulative leaching loss of applied N, P and $S$ was observed in $T_{2}$ treatments followed by $\mathrm{T}_{1}$. The highest loss might be due to higher rate of chemical fertilizer application. The lowest leaching loss of applied N, P and S was found in control treatment. The reason of the lowest loss in control plot might be due to no added fertilizer. It was also reported by Islam et al., $2013 \mathrm{~b}$. Treatments $\mathrm{T}_{3}, \mathrm{~T}_{4}$ and $\mathrm{T}_{5}$ showed similar leaching loss of $\mathrm{NH}_{4}{ }^{+}-\mathrm{N}, \mathrm{NO}_{3}{ }^{-}-\mathrm{N}$ and $\mathrm{P}$ at different DAT. Nitrogen and $\mathrm{P}$ leaching loss increased rapidly after 45 DAT and again slowly after 75 DAT in $\mathrm{T}_{1}$ and $\mathrm{T}_{2}$. Nitrogen loss increased after urea application, because urea fertilizer dissolved rapidly. On the other hand, TSP ( $\mathrm{P}$ fertilizer) might be taken more time to become soluble. In case of USG application, $\mathrm{N}$ losses rate was stable over time. The cause behind that finding might be slow conversion of $\mathrm{N}$ at reduced zone (Lamb et al., 2014). Sulfur leaching loss rapidly increased from 30-45 DAT and then remains stable in $T_{1}$ and $T_{2}$. The reason might be less amount of available $S$ was present after specified time. Leaching loss of $S$ was stable over the growing periods in $\mathrm{T}_{0}, \mathrm{~T}_{3}, \mathrm{~T}_{4}$ and $\mathrm{T}_{5}$ (Fig. 10). On the other hand, cumulative leaching loss of applied $\mathrm{K}$ was followed similar pattern among all treatments over time (Fig. 9).
About 44.35, 40.72, 42.57, 32.93 and $28.26 \%$ of applied $\mathrm{N}$ was lost through leaching in $T_{1}, T_{2}, T_{3}, T_{4}$ and $T_{5}$, respectively. Leaching loss of $\mathrm{N}$ in the form of $\mathrm{NH}_{4}{ }^{+}-\mathrm{N}$ was $37.53 \%$ while $6.74 \%$ applied $\mathrm{N}$ was lost as $\mathrm{NO}_{3}-\mathrm{N}$ in $\mathrm{T}_{1}$. In other treatments, almost similar trends were found. Leaching loss of $\mathrm{P}$ in $\mathrm{T}_{1}, \mathrm{~T}_{2}, \mathrm{~T}_{3}, \mathrm{~T}_{4}$ and $\mathrm{T}_{5}$ was $0.65,0.59,0.18,0.27$ and $0.28 \%$, respectively. Potassium lost through leaching was $1.74,2.06,0.43,0.87$ and $0.87 \%$ in $T_{1}, T_{2}, T_{3}, T_{4}$ and $T_{5}$, respectively. Leaching loss of $S$ in $T_{1}, T_{2}, T_{3}, T_{4}$ and $T_{5}$ was 44.74, 47.37, 5.26, 11.84 and 21.05\%, respectively. Although application of chemical fertilizer at higher rates resulted in greater amount of $\mathrm{N}$ and $\mathrm{P}$ loss, it was not greater than recommended dose. However, in case of $\mathrm{K}$ and $\mathrm{S}$, higher rates of application resulted in higher rate of leaching loss.

Total leaching loss of $\mathrm{NH}_{4}{ }^{+}-\mathrm{N}, \mathrm{NO}_{3}{ }^{-}-\mathrm{N} \mathrm{P}$, $\mathrm{K}$ and $\mathrm{S}$ in sandy loam soil during Boro rice culture under different treatments ranged from 12.91 to $74.34,3.09$ to $15.87,0.07$ to 0.29 , 9.60 to 11.20 and 3.75 to $17.81 \mathrm{~kg} \mathrm{ha}^{-1}$, respectively. Total $\mathrm{N}$ loss during study period ranged from 16.00 to $90.21 \mathrm{~kg} \mathrm{ha}^{-1}$ (Table 1). Slow release of nutrients from the organic manure might have resulted in lowering the loss of nutrients for $\mathrm{T}_{3}$. Again, due to USG deep placement $\left(\mathrm{T}_{4}\right)$ the losses of $\mathrm{N}$ were lower. Losses of $\mathrm{P}, \mathrm{K}$ and $\mathrm{S}$ were also minimum in USG treated pot. Minimum loss of $\mathrm{P}, \mathrm{K}$ and $\mathrm{S}$ might be due to more vegetative

Table 1. Total leaching loss of NPKS in sandy loam soil under AWD condition (kg ha-1), BAU, Mymensingh.

\begin{tabular}{|c|c|c|c|c|c|c|}
\hline \multirow[t]{2}{*}{ Treatment } & \multicolumn{3}{|c|}{$\mathrm{N}$} & \multirow[t]{2}{*}{$\mathrm{P}$} & \multirow[t]{2}{*}{ K } & \multirow[t]{2}{*}{$S$} \\
\hline & $\mathrm{NH}_{4}{ }^{+}-\mathrm{N}$ & $\mathrm{NO}_{3}-\mathrm{N}$ & Total & & & \\
\hline $\mathrm{T}_{0}$ & 12.91 & 3.09 & 16.00 & 0.07 & 9.60 & 3.75 \\
\hline $\mathrm{T}_{1}$ & 58.34 & 11.25 & 69.59 & 0.23 & 10.46 & 12.58 \\
\hline $\mathrm{T}_{2}$ & 74.34 & 15.87 & 90.21 & 0.29 & 11.20 & 17.81 \\
\hline $\mathrm{T}_{3}$ & 46.45 & 8.67 & 55.12 & 0.12 & 9.79 & 4.73 \\
\hline $\mathrm{T}_{4}$ & 42.97 & 8.75 & 51.72 & 0.14 & 9.92 & 6.09 \\
\hline $\mathrm{T}_{5}$ & 41.84 & 8.34 & 50.18 & 0.14 & 9.97 & 7.87 \\
\hline
\end{tabular}

$\mathrm{T}_{0}=$ control, $\left.\mathrm{T}_{1}=\mathrm{NPKS}\left(120,25,60 \text { and } 20 \mathrm{~kg}^{-1}\right)^{-1}\right) \mathrm{T}_{2}=\operatorname{NPKS}\left(180,37,90\right.$ and $\left.30 \mathrm{~kg} \mathrm{ha}^{-1}\right), \mathrm{T}_{3}=\mathrm{NPKS}(90,5$, 28 and $\left.17 \mathrm{~kg} \mathrm{ha}^{-1}\right)+\mathrm{cow}$ dung $\left(2.5 \mathrm{t} \mathrm{ha}^{-1}\right), \mathrm{T}_{4}=\mathrm{NPKS}\left(109,25,60\right.$ and $20 \mathrm{~kg} \mathrm{ha}^{-1}, \mathrm{~N}$ as USG) and $\mathrm{T}_{5}=$ as $\mathrm{T}_{1}$ but $\mathrm{N}$ applied as foliar spray. 
growth of plant and more uptake of nutrient. The reason for lowering of leaching loss of $\mathrm{N}$ from the foliar spray treatment is quite obvious (Islam et al., 2014). Application of chemical fertilizer at higher rates resulted in greater amount of nutrient leaching loss. Similar observations were found by Islam et al., (2013a), Islam et al., (2013b) and Islam et al., (2014).

\section{CONCLUSION}

Leaching loss of $\mathrm{N}, \mathrm{P}, \mathrm{K}$ and $\mathrm{S}$ from sandy loam soil (Old Brahmaputra Floodplain, AEZ9) under AWD condition for Boro rice cultivation was quite significant. Application of chemical fertilizer at higher rates resulted in greater loss of nutrients. Integrated fertilizer management using cowdung could minimize such losses to some extent. Application of $\mathrm{N}$ in the form of USG might be helpful in reducing loss of $\mathrm{N}$ appreciably.

\section{REFERENCES}

BARC (Bangladesh Agricultural Research Council). 1997. Fertilizer Recommendation Guide. Bangladesh Agril. Res. Council, Farmgate, New Airport Road, Dhaka-1215. iii. 1, 2, 6.

Black, C A. 1965. Methods of Soil Analysis. Part I \& II. American Soc. Agron. Inc. Pub. Madison, Wisconsin, USA.

Camberato, J, J Brad and R L Nielsen. 2008. Nitrogen loss in wet and wetter fields. Corney News Network, Purdue University. URL: http:/ / www.kingcorn.org/ de Oliveira, M W, P C O Trivelin, A E Boaretto, T Muraoka and J Mortatti. 2002. Leaching of nitrogen, potassium, calcium and magnesium in a sandy soil cultivated with sugarcane. J. Pesq. Agropec. Bras., Brasilia, 37(6): 861-868.

Hodges, S C. 2010. Soil Fertility Basics. Soil Science Extension, North Carolina State University.

Islam, M N, M M Rahman, M J A Mian, R Barua and A M Kamal. 2013a. Leaching loss of NPKS in the Old Brahmaputra Floodplain soil under continuous standing water condition. Eco-friendly Agril. J. 6(04): 63-66.

Islam, M N, M M Rahman, M J A Mian, R Barua and A M Kamal. 2013b. Leaching loss of NPKS in silty soil under alternate wetting and drying condition. Eco-friendly Agril. J. 6(04): 67-71.

Islam, M N, M M Rahman, M J A Mian, M H Khan and R Barua. 2014. Leaching losses of nitrogen, phosphorus and potassium from the sandy loam soil of Old Brahmaputra Floodplain (AEZ-9) under continuous standing water condition. Bangladesh J. Agril. Res. 39(3): 437446.

Meisinger, J J, J A Delgado and A K Alva. 2006. Nitrogen leaching management. Ency. of Soils in the Environ. 2: 1122-1124.

Page, A L, R H Miller and D R Keeney. 1989. Methods of Soil Analysis. Part II. 2nd ed. Amer. Soc. of Agron. Inc. Pub. Madison, Wisconsin, USA.

Pieri, C and R Oliver. 1986. Assessment of $\mathrm{K}$ losses in tropical cropping systems of francophone Africa and Madagascar. Proceeding $13^{\text {th }}$ Congress Int. Potash Inst., Bern: 73-92.

Sahu, S K and P K Samant. 2006. Nitrogen loss from rice soils in Orissa. Orissa review, December 2006.

Sharpley, A N. 1997. Rainfall frequency and nitrogen and phosphorus runoff from soil amended with poultry litter. J. Environ. Qual. 26: 1127-1132.

Lamb, J A, F G Fernandez and D E Kaiser. 2014. Understanding nitrogen in soils. University of Minnesota. AG-FO-3770-B (Revised 2014). 